International Journal of Agriculture, Environment and Bioresearch

Vol. 5, No. 06; 2020

ISSN: $2456-8643$

\title{
SOIL SEED BANKS IN TWO TROPICAL FOREST TYPES: ON THE RELEVANCE OF SAMPLING DEEP SOIL LAYERS
}

\author{
Chauvelin Douh ${ }^{1,2^{*}}$, Pierre Mbete ${ }^{1,2}$, Saint Fédriche Ndzaï ${ }^{1,2}$, Félix Koubouana ${ }^{1,2}$ \\ ${ }^{1}$ Université Marien NGOUABI, Ecole Nationale Supérieure d'Agronomie et de Foresterie (ENSAF), BP. 69 \\ Brazzaville, Congo \\ ${ }^{2}$ Laboratoire de Géomatique et d'Ecologie Tropicale Appliquées (LGETA)
}

https://doi.org/10.35410/IJAEB.2020.5593

\begin{abstract}
The soil seed banks play a crucial role in the resilience of forests to disturbance. Sampling strategies are generally limited to the first 10 or 15 centimetres of the soil while deeper layers could conceal specific taxa. This study evaluates the variability of the seed bank as a function of depth or type of soil in two rainforests in the Congo. At each study site, 30 samples were taken per soil layer (litter, $0-5 \mathrm{~cm}, 5-10 \mathrm{~cm}$ and $10-20 \mathrm{~cm}$ ). The diversity and abundance of the seeds were estimated after they were brought to germination. Two means of estimating the species richness and the rarefaction curves were used in order to estimate the diversity of the flora in each layer of soil. The results showed great variability between types of forest. They also highlighted greater diversity and higher abundance in the first 10 centimetres of soil. However, the proportions were nonetheless not negligible between 10 and $20 \mathrm{~cm}$, and $21 \%$ of plant species were encountered exclusively in this layer. The latter may therefore have a fundamental role in the resilience of forests to anthropogenic disturbances, including logging. Complementary studies are indispensable in order to better understand this role as well as the factors which have an effect on the temporal and spatial variability of the soil seed bank.
\end{abstract}

Keywords: soil seed bank; rarefaction curve; species richness; forest resilience; rainforests.

\section{INTRODUCTION}

The soil seed bank, which designates the stock of viable seeds present in the soil (Roberts, 1981; Garwood, 1989), has an important role in the maintenance of the ecological diversity of natural ecosystems (Livingstone and Allessio, 1968; Thompson and Grime, 1979; Brown and Venable, 1986; Houle and Phillips, 1988). Seeds buried in the soil may be brought back to the surface either by movements of roots or by organisms living in the soil or by anthropogenic disturbances (Vasquez-Yanes and Orozco-Segovia, 1993). For example, logging activities disturb the top soil by creating roads and skidding timber (Kleinschrot et al., 2015). The subsequent resilience of the forest will depend on the abundance of seeds and their germination rates in the different disturbed layers (Fayolle et al., 2014). Despite a growing number of studies on this subject, the sampling protocols are very variable from one study to another. Typically, a characterisation of the soil seed bank of a region necessitates samples from a soil of known dimensions, which are then placed in optimal conditions for germination. The vast majority of studies touching on this 
subject carry out unitary sampling which is on a small scale and focus on the first centimetres of soil (Shen et al., 2014).

However, the procedures of sampling soil in order to study the seed bank are far from being unanimously accepted. For example, even though most of these studies take samples corresponding to a total surface area of less than $1 \mathrm{~m}^{2}$ (e.g. Moles et al., 1999; Hosogi et al., 2006; Dainou et al., 2011), Shen et al. (2014) recently demonstrated that it is necessary to collect almost four times as much in order to estimate the floristic richness of the emperate forest soil seed bank. Similarly, most studies concentrate sampling on the first 5 to 10 centimetres of the soil (Pakeman \& Small, 2005; Hosogi et al., 2006; Martins \& Engel, 2007; Dainou et al., 2011). However, taking into account the deeper layers may be necessary given that (i) numerous studies have demonstrated that the viability of seeds seems to grow with depth, some taxa display life durations close to a century; (ii) the abundance of certain species increases with depth they belong to the species of the first stages of plant succession, species which may no longer be represented in the surrounding environment (Warr et al., 1993 ; Grandin and Rydin, 1998; Csontos and Tamas, 2003).

Finally, the nature of the substrate may play a crucial role in the soil seed bank. It may not only influence the abundance of seed banks, independently of the densities of population of the forest stand (Warr et al., 1993), but also promote the emergence of the buried seeds. In particular, sandy soils, which are more mobile than heavy clay soils, tend to have more frequent emergences (Zhang and Maun, 1994; Leicht-Young et al., 2009).

In Central Africa, studies dealing with the soil seed bank are extremely rare (Daïnou et al., 2011), and have never concentrated on the variability of the seed bank as a function of depth or the type of soil. This paper concentrates on these questions, considering the environmental context of two tropical rainforests, developing on two different substrates in the north of the Republic of Congo. More specifically, it studies the characteristics of the soil seed bank at depths rarely studied, between 10 and $20 \mathrm{~cm}$. The hypotheses orienting the study are: (1) the characteristics of the soil seed bank vary significantly depending on the depth and the substrate; (2) deep layers conceal a not inconsiderable seed bank; (3) the specific species of deep layers are characteristic of pioneer taxa.

\section{MATERIALS AND METHODS}

\subsection{Study sites}

The study was carried out in two rainforests in the north of the Republic of Congo. The first site, within the forest management unit attributed to CIB/OLAM, is close to Loundoungou Forests (FL). The second site, within the forest management unit of Mokabi-Dzanga, is close to Mokabi Forests (FM). FL and FM extend respectively between $02^{\circ} 18^{\prime}-02^{\circ} 22^{\prime} \mathrm{N}$ and $17^{\circ} 31^{\prime}-17^{\circ} 34^{\prime} \mathrm{E}$ then $03^{\circ} 01^{\prime}-03^{\circ} 37^{\prime} \mathrm{N}$ and $16^{\circ} 30^{\prime}-17^{\circ} 22^{\prime} \mathrm{E}$ (Figure 1). The two areas are relatively flat with average altitudes between $430 \mathrm{~m}$ and $530 \mathrm{~m}$. They display a bimodal distribution of seasonal precipitation. The average annual rainfalls and the average temperatures are $1729 \mathrm{~mm}$ and $25^{\circ} \mathrm{C}$ for FL, and $1670 \mathrm{~mm}$ and $24^{\circ} \mathrm{C}$ for FM (Bégué, 1967). The two sites differ with respect to the composition of their flora and substrate: the Loundoungou forests are semi-deciduous, and are located on clay soils developing on alluvial deposits in the Cuvette of the Congo. The Mokabi 
forests are transitional forests between the semi-deciduous and evergreen types, established on sandy soils on the sandstones of Carnot.

In terms of chemical fertility, the soils of FM are relatively poorer than those of FL (Boulvert, 1996; Verelst, 2009; Fayolle et al., 2012; Freycon, 2014). The Loundoungou forests shelter numerous species typical of old secondary forests such as Erythrophleum suaveolens, Triplochiton scleroxylon and Terminalia superba. Those Mokabi forests have a composition which is typical of more mature forests, with species such as Prioria oxyphylla, Staudtia kamerunensis, Polyalthia suaveolens, Manilkara mabokeensis, Autranella congolensis) (Fayolle et al., 2012 ; Gond et al., 2013).

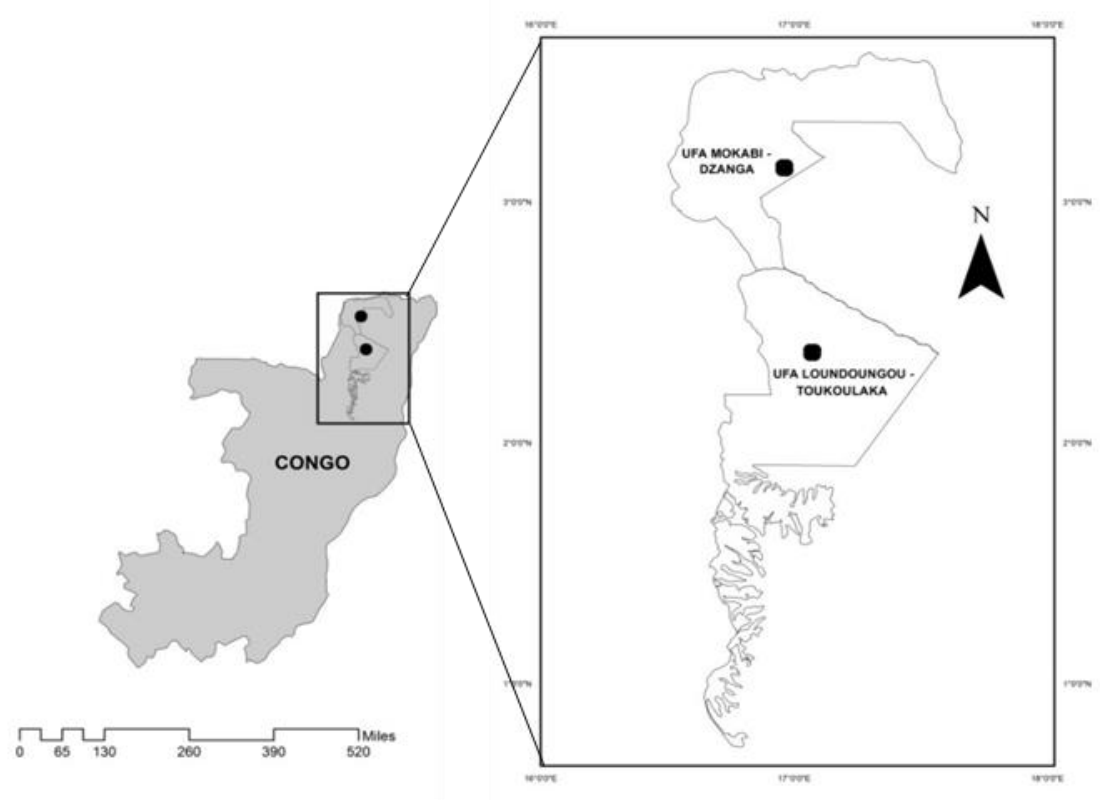

Figure 1. Location of the two study sites in the forest management units of Mokabi (FM) and Loundoungou (FL).

\subsection{Sampling strategy and seedling emergence test}

The soil samples were taken in January 2015, during the transition between the long dry season and the short rainy season. On each of the two sites, the soil samples were collected in a plot of 4 $\mathrm{km}^{2}(2 \times 2 \mathrm{~km})$ monitored by the DynAfFor project (Picard and Gourlet-Fleury, 2008). Within each plot, five parallel trails of $2 \mathrm{~km}$ length each were used for the implantation of sampling points. Six collection points at intervals of $300 \mathrm{~m}$ were set up on each trail, making a total of 30 collection points per site (Figure 2). Four layers of soil were sampled for each point: litter, 0-5 $\mathrm{cm}, 5-10 \mathrm{~cm}$ and 10-20 cm. Each sample was a composite one, in other words a mix of three unitary samples carried out at the points of an equilateral triangle of $1 \mathrm{~m}$ side length (Perera, 2005; Daïnou et al., 2011). Each sample covered a surface area of $100 \mathrm{~cm}^{2}(10 \times 10 \mathrm{~cm})$. The surface area sampled per plot was consequently $0.9 \mathrm{~m}^{2}$. The depth of the samples was $5 \mathrm{~cm}$ for the $0-5 \mathrm{~cm}$ and $5-10 \mathrm{~cm}$ layers. It was $10 \mathrm{~cm}$ for the $10-20 \mathrm{~cm}$ layer. The number of viable seeds in the soil was estimated by the method of germination (van der Valk \& Davis, 1978). The 
Vol. 5, No. 06; 2020

ISSN: $2456-8643$

samples were sieved before the beginning of the experiment, in order to eliminate crude plant and mineral matter (e.g. leaves or pieces of wood).

The germination was carried out in a greenhouse at the semi-industrial nursery of the SNR (National Reforestation Service) in Brazzaville, in a non-forest zone in order to limit the risk of contamination of the samples by the surrounding vegetation. The relative luminous intensity was about $30-40 \%$ of full light. Each soil sample was spread out over a layer of sand-substrate mixture with a thickness of approximately $1 \mathrm{~cm}$ (Hall \& Swaine, 1980; Dalling et al., 1994). The substrate was previously decontaminated of any seed by heating (Hall \& Swaine, 1980). Watering was almost daily, and checking of the germinations was biweekly. When their development stage allowed it, the seedlings were removed and planted individually in polyethylene bags in order to favour their growth and identification. As all of the germinations took place over the course of the next 12 weeks, the experience finished at the end of 16 weeks.

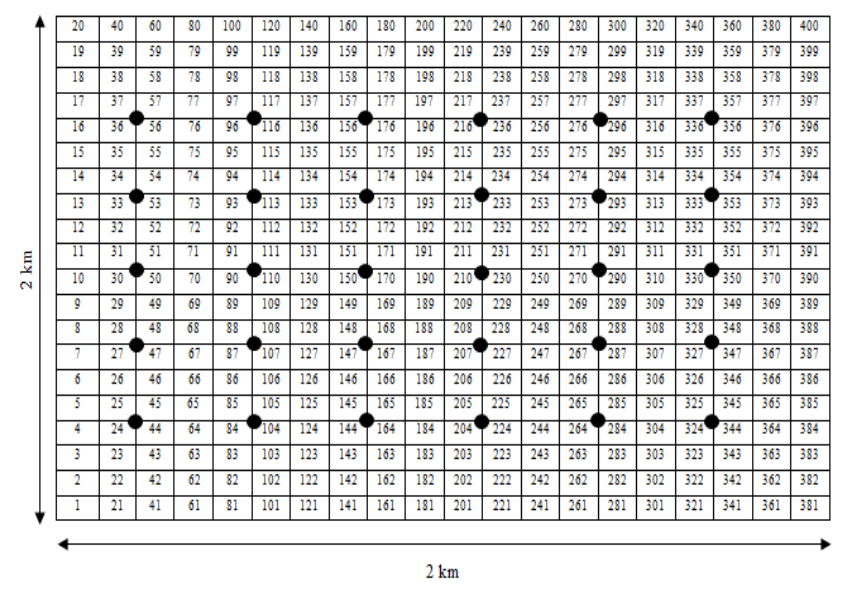

Figure 2. Sample design of the soil seed bank on a plot of 400 ha. Symbols: black circle $=$ point of collection of soil samples; square with number $=1$ ha.

\subsection{Data analysis}

We computed the species richness observed (Walther et al., 2005), but for comparison we used the estimators Chao2 (and its "bias-corrected" version, both being based on incidence) and Jackknife1 (based on abundance) n $S_{o b s}$ being very dependent on the sampling effort (Poulin, 1998; Walther and Morand, 1998; Walther and Martin, 2001; Chiarucci et al., 2003; Dove and Cribb, 2006). The program EstimateS 9.1.0 (Colwell, 2013) was used in order to generate both the observed species richness $S_{o b s}$ and the estimated richnesses, $S_{c h a o 2}$ (bias-corrected Chao2) and $S_{\text {jackl }}$. These two types of richness were illustrated by rarefaction curves. Finally, the density of viable seeds per layer was calculated by accumulating the data of each point per level of soil. A redundancy analysis RDA was carried out for each site on the basis of the Hellinger distances between samples (Rao, 1995; Legendre and Gallagher, 2001). The samples not having provided any germination were excluded from the analysis. The RDA was carried out with the program $R$ and the Vegan package. The indices of Sorensen and Morisita-Horn were used in order to evaluate the similarity of the soil seed bank between the layers of the same site. Compared with 
the Sorensen index, the Morisita-Horn index is more sensitive to abundant species in the communities compared (Chao et al., 2006).

Finally, the specificity of layers in terms of species found exclusively in each layer was determined by comparing these "characteristic" species with the total number of species found in the layers $\left(\% \mathrm{~S}_{\text {char }}\right)$.

\section{RESULTS}

\subsection{Species richness and seed abundance among layers}

The layers of the FL site generally display a greater richness than those of the FM site. The rarefaction curves of richness estimated by Chao 2 demonstrate that the values are closer to the asymptote in the layers of FM (Figure 3).

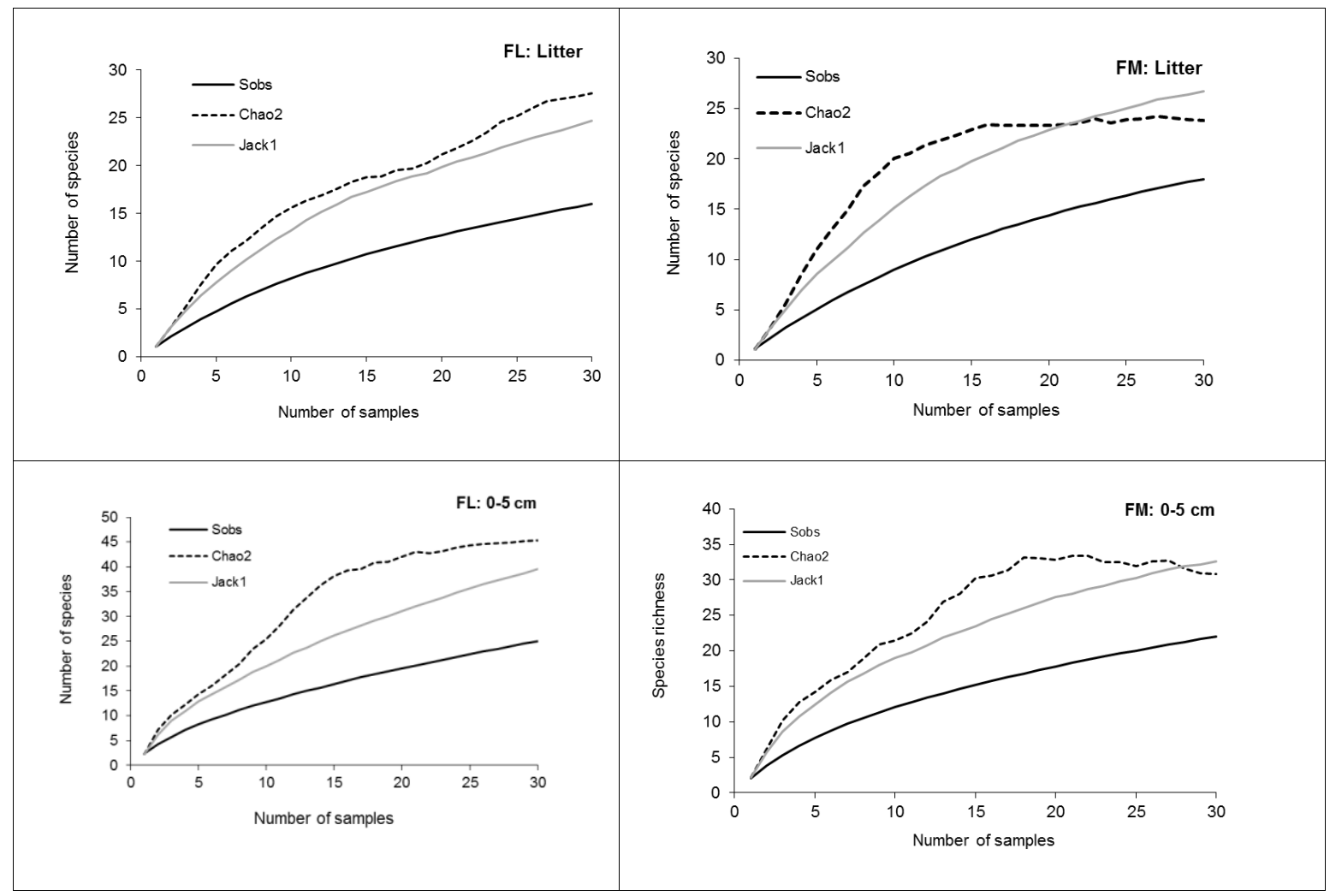


Vol. 5, No. 06; 2020

ISSN: $2456-8643$

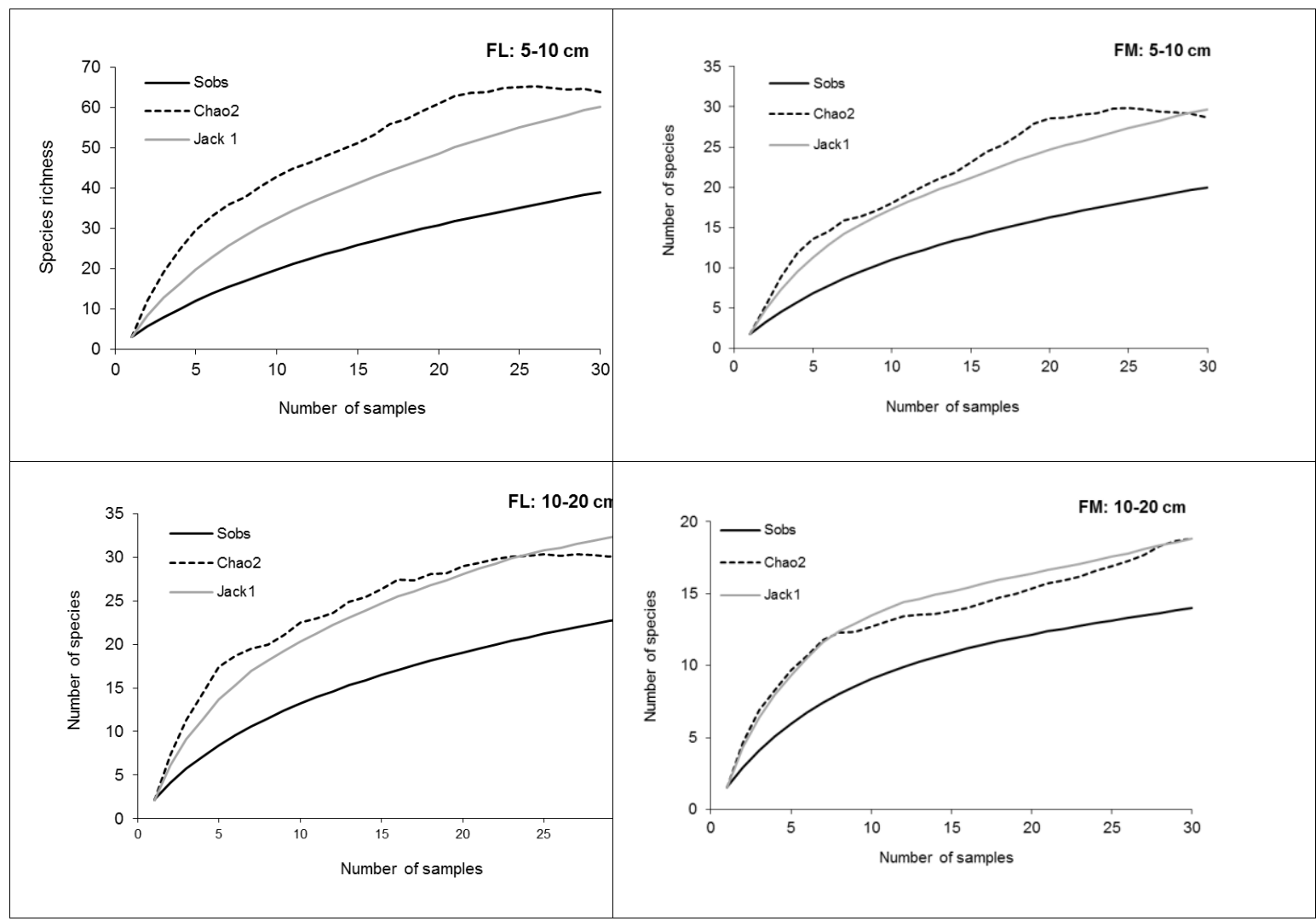

Figure 3. Rarefaction curves for each layer of the two sites studied.

Whatever the means of estimation considered, the two intermediate layers, $0-5 \mathrm{~cm}$ and $5-10 \mathrm{~cm}$, display the highest richnesses (Table 1). At the FL site, the estimated richness in the $5-10 \mathrm{~cm}$ layer, approximately 60 species, is twice as high as that of the "litter" and 10-20 cm layers. At the FM site, the two intermediate layers have similar richnesses, of around 30 species. The lowest richness for FL is observed in the litter, with $25-28$ species, whereas it is the $10-20 \mathrm{~cm}$ layer which is the least rich for FM, with 19 species.

Table 1. Specific richnesses, observed ( $\left.S_{\text {obs }}\right)$ and estimated $\left(S_{\text {jack1 }}, S_{\text {chao } 2}\right)$, and percentages of characteristic species $\left(\% \mathrm{~S}_{\text {char }}\right)$ of the layers of soil at the two sites, FL (clay soil) and FM (sandy soil).

\begin{tabular}{|l|l|l|l|l|l|l|l|l|}
\hline \multirow{2}{*}{ Layers } & FL & \multicolumn{9}{l|}{ FM } \\
\cline { 2 - 9 } & $\mathrm{S}_{\text {obs }}$ & \% $\mathbf{S}_{\text {char }}$ & $\mathrm{S}_{\text {chao2 }}$ & $\mathrm{S}_{\text {jack1 } 1}$ & $\mathrm{~S}_{\text {obs }}$ & S $_{\text {char }}$ & $\mathrm{S}_{\text {chao2 }}$ & $\mathrm{S}_{\text {jack1 }}$ \\
\hline Litter & 16 & 31.3 & 27.6 & 24.7 & 18 & 16.7 & 27.6 & 23.8 \\
\hline $0-5 \mathrm{~cm}$ & 25 & 4.0 & 45.3 & 39.5 & 22 & 27.3 & 30.9 & 32.6 \\
\hline $5-10 \mathrm{~cm}$ & 39 & 28.2 & 63.8 & 60.3 & 20 & 25.0 & 28.7 & 29.7 \\
\hline $\begin{array}{l}10-20 \\
\mathrm{~cm}\end{array}$ & 23 & 21.8 & 30.3 & 32.7 & 14 & 21.4 & 18.8 & 18.8 \\
\hline
\end{tabular}


In terms of density, the tendency observed with respect to the specific richness remains the same: the intermediate layers $0-5 \mathrm{~cm}$ and $5-10 \mathrm{~cm}$ show higher densities than those of other layers, with values between 86 and 123 seeds $/ \mathrm{m}^{2}$ at FL, and around 70 seeds $/ \mathrm{m}^{2}$ at FM (Table 2). At both sites, the proportion of seeds observed in the $10-20 \mathrm{~cm}$ layer represents around $25 \%$ of the seed bank of the site.

Table 2. Seed abundance among layers in the two studied sites (number of seeds $/ \mathrm{m}^{2}$ )

\begin{tabular}{|l|l|l|}
\hline Layers & FL & FM \\
\hline Litter & $41.1 \pm 4.4$ & $38.9 \pm 4.2$ \\
\hline $0-5 \mathrm{~cm}$ & $86.7 \pm 8.8$ & $73.3 \pm 7.6$ \\
\hline $5-10 \mathrm{~cm}$ & $123.3 \pm 11.5$ & $68.9 \pm 6.7$ \\
\hline $10-20 \mathrm{~cm}$ & $78.9 \pm 7.2$ & $63.3 \pm 6.3$ \\
\hline
\end{tabular}

\subsection{Overall comparison of seed bank composition among layers}

The comparison of the layers using an RDA on the basis of the distance of Hellinger between samples reveals overall that the characteristics of seed banks are rather similar in each layer, even though some samples stand out (Figure 4).

In both cases, no species is strongly associated with an axis (annexe 1), and it is necessary to consider the first five axes in order to obtain an explained variance of at least 20\% (regular decline of eigenvalues; annexe 1). Axes 1 and 2 represented on Figure 4 explain respectively total $9.3 \%$ and $10.2 \%$ of the total variance in FL and FM. 
International Journal of Agriculture, Environment and Bioresearch

Vol. 5, No. 06; 2020

ISSN: $2456-8643$

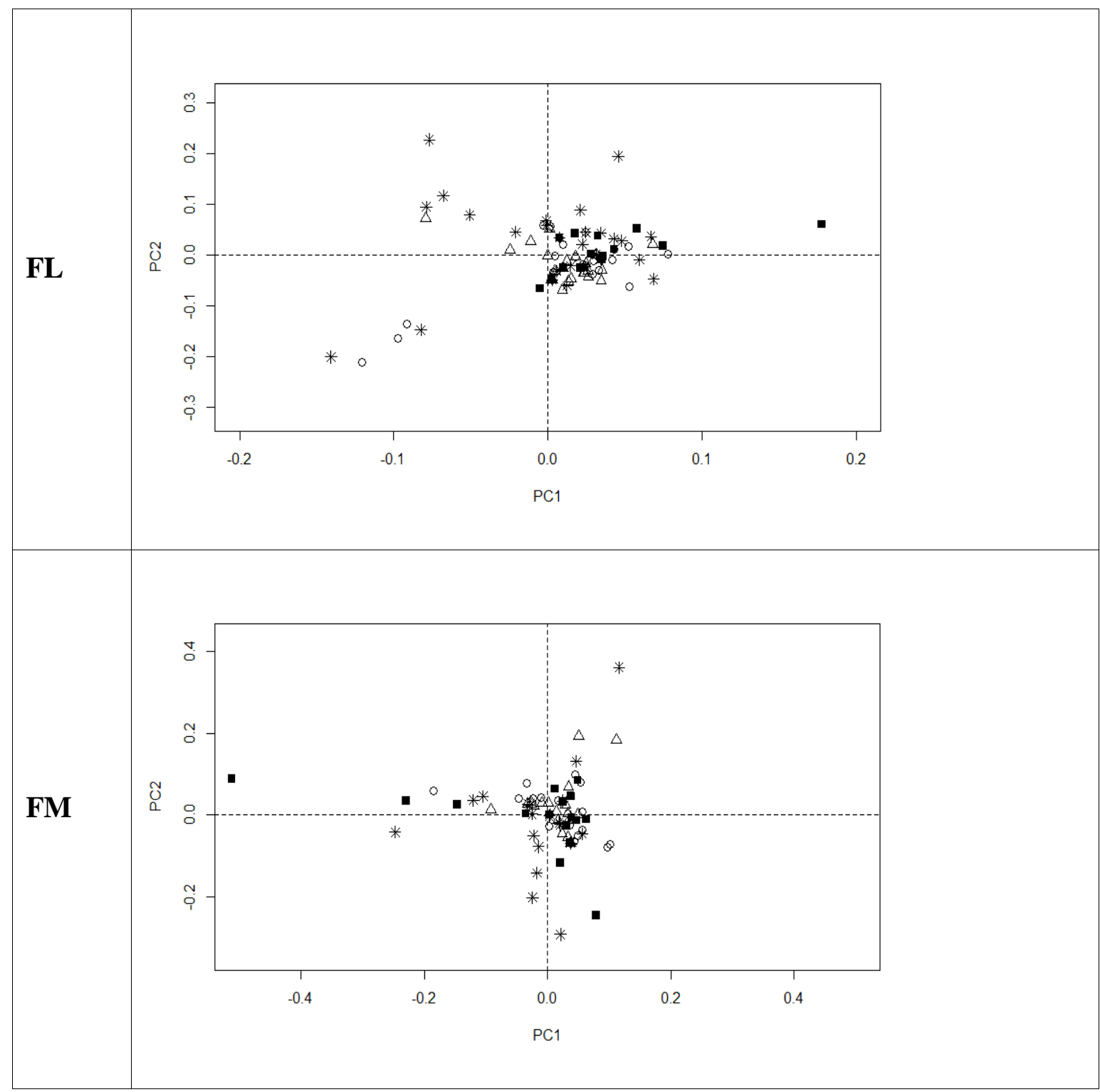

Figure 4. RDA carried out on the data of specific abundance of the layers of each site. Symbols: black square $=$ litter; empty circle $=0-5 \mathrm{~cm} ;$ star $=5-10 \mathrm{~cm}$; triangle $=10-20 \mathrm{~cm}$.

A certain specificity of the different layers is noted. In fact, apart from the $0-5 \mathrm{~cm}$ layer in the FL site, for which the proportion of characteristic species is virtually negligible, all of the other layers, including the deepest of each site, display rates of characteristic species which are generally higher than $20 \%$ (Table 1). The characteristic taxa for the FL site are: litter layer: $23 \%$; $0-5 \mathrm{~cm}$ layer: $4 \% ; 5-10 \mathrm{~cm}$ layer: $50 \% ; 10-20 \mathrm{~cm}$ layer: $20 \%$. The characteristic taxa for the FM site are: litter layer: $18 \%$; 0-5 cm layer: $35 \%$; 5-10 cm layer: $29 \%$, and $10-20 \mathrm{~cm}$ layer: $18 \%$.

\section{DISCUSSION}

The results of this study display the first tendencies showing the relevance of sampling the deeper layers of soil in rainforest of Central Africa. Even though the proportions and the species 
Vol. 5, No. 06; 2020

ISSN: $2456-8643$

richness are the highest between 0 and $10 \mathrm{~cm}$ of depth, the 10-20 cm layer is overflowing with species which are peculiar to it, as more than $21 \%$ of the species found are from this layer. Even though these observations are valid for both of the sites studied, one of the two sites are distinguished by its higher overall proportions and diversities.

\subsection{Abundance and diversity per soil layer}

Various mechanisms, of abiotic and biotic origin, explain the movements of seeds in the soil. Movements of roots, the subsidence of soil around the roots, the splashing effect of raindrops, the action of burrowing rodents, and the movement of earthworms and of arthropods all take part in the burying and exhumation of soil seeds (Plue \& Hermy, 2012).

Several studies have demonstrated that, generally, the proportion of seeds in the soil diminishes progressively with depth (for instance Kellman, 1970; Moore \& Wein, 1977; Putz, 1983; Putz \& Appanah, 1987; Kramer and Johnson, 1987). Perera (2005) reported that at least 70\% of seeds were stored in the first four centimetres of the soil in tropical semi-deciduous forests of Sri Lanka.

Nonetheless, opinions diverge on this overall tendency: Young et al. (1987), report an almost uniform distribution in a tropical forest of Costa Rica. There are great variabilities depending on the species considered: some species are more abundant in the upper layers and others in the intermediate layers, whereas another group seems to be best represented in the deepest layers (Warr et al., 1993). The capacity to germinate a priori seems to be better for seed stores in the upper layers, which are made up of more recent deposits than those of deeper layers. The latter contain more seeds which have been dormant for longer (Ray et al., 1983). Rampton \& Ching (1970) are of the opinion that the viability of seeds increases with their depth of burying in the soil, and that this viability may last greater than a century but there are very few studies on seed banks relating to layers reaching a depth of $20 \mathrm{~cm}$.

The pioneer species of the first stages of succession display more dormant seeds than the species of later stages (Hall and Swaine, 1980; Garwood, 1989). Moreover, these pioneer species are generally seeds of smaller dimensions which are likely to escape the effect of granivorous animals, which may explain their dominance in seed banks (Venable, 1989). According to Page et al (2006), the number of unobserved species varies according to the circumstances, and it is necessary to use means of estimating the specific richness in order (1) to evaluate the reliability of the sampling, (2) to give a precise value of the species richness. Heck et al. (1975) and Karakassis (1995) nonetheless remind that studies of species richness must deal with homogenous groupings, and that the stratification of communities may be indispensable. Our study was carried out with forest stands of which an inventory had previously been made (DynAfFor project), displaying a homogeneous floristic composition over the area of sampling. The results which emerge are therefore not biased by any heterogeneity of the groupings. The proportion of richness directly revealed by the study, in comparison with that suggested by the "bias-corrected Chao2", varies between 58-65\% in the first layers and 74-76\% in the deep layer $(10-20 \mathrm{~cm})$. However, the curves of rarefaction based on the Jackknife estimator do not in fact converge towards the asymptote for any layer. According to Walther et al. (2005) and Marcon 
(2016), this reflects insufficient sampling, even though a total surface area of $1.8 \mathrm{~m}^{2}$ was sampled in our two sites.

\subsection{Inter-site variation}

The layers of the FL display a greater richness than do those of the FM, more precisely at the two intermediate layers, $0-5 \mathrm{~cm}$ and $5-10 \mathrm{~cm}$. The floristic composition of the FL corresponds to a semi-deciduous forest, with a more marked seasonality: the species with dormant seeds may therefore be greater in number there (Martins and Engel, 2007; Chen et al., 2013). This forest has also experienced numerous anthropogenic disturbances in the past (Oslisly et al., 2013; MorinRivat et al., 2014); it is therefore younger and more dominated by light-demanding species. According to Han et al (2012), the light-demanding species of the first stages of plant succession produce many more seeds than the species of mature forests and, consequently, display more dormant seeds than the species of mature forests.

However, Alvarez-Aquino et al (2005) specify that forests having been subjected to disturbances in the past conceal greater proportions of soil seed banks dominated by pioneer species. This suggests that the disturbed forests at the FL site may have a greater potential for regeneration compared to forests at the FM site, which are typical of more mature forests.

Moreover, pioneer trees adapt better to deteriorated environments, and the germination of their seeds is inherently linked with a strong light intensity created by the degree of opening of the canopy (Pearson et al., 2003).

The nature of the soil, principally its acidity and porosity, may also have an influence on the abundance of the seed bank, although these influences have mainly been studied in temperate zones and savannahs (Wilson and Witkowski, 2003; Witkowski and Garner, 2008). The few studies realised in tropical forests of Asia and America (Chen et al., 2013; dos Santos et al., 2013) tend to demonstrate that the soil seed banks were more developed in relatively rich soils, compared with relatively poor soils. The survival of the soil seed bank of tropical forests could be correlated with the quantity of nutritive reserves in the soil (Osunkoya et al., 1992; Hammond and Brown, 1995; Baraloto, 2001). The FM, based on soils characterised by a low availability of resources such as water and nutrients (Fayolle et al., 2012) could be less favourable for the conservation of seeds in comparison with the FL site, which is based on clay soils and which is characterised by high availability of resources such as water and nutrients (Fayolle et al., 2012).

\section{CONCLUSION}

Our results show a significant variability in the soil seed bank, on the one hand between soil layers, and on the other hand between sites. The presence of seeds only found in the $10-20 \mathrm{~cm}$ layer may have some notable implications, in particular with respect to the resilience of forests to anthropogenic disturbances, including logging activities. Logging is the most significant form of legal occupation of land in the Congo Basin (Nasi et al., 2012). The speed of recolonization of the roads, skidding trails and gaps depends on the soil seed bank (Kleinschrot et al., 2015). During exploitation activities, the soil may be disturbed to non-negligible depths, and so the abundance and diversity of seeds present in the soil are fundamental constituents of forest recolonization. The factors determining the spatial and temporal variation of the soil seed bank 
Vol. 5, No. 06; 2020

ISSN: $2456-8643$

and its development in forest stands exploited by man should therefore be studied in detail in order to gain a better understanding thereof.

\section{Acknowledgements}

The authors wish to thank Marien NGOUABI University (Republic of the Congo), the University of Liège and its faculty Gembloux Agro-Bio Tech (Belgium), the PEFOGRN-BC projects (support project for the wider programme of training in natural resources management in the Congo Basin), the associations Nature + and DynAfFor project (Dynamique des Forêts d'Afrique Centrale, Dynamics of Central African Forests), as well as the logging companies Mokabi-Dzanga (Groupe Rougier) and CIB/OLAM for their financial, scientific and technical support, and for their aid with fieldwork.

\section{REFERENCES}

Alvarez-Aquino, C., Williams-Linera, G. \& Newton, A.C., 2005. Disturbance effects on the seed bank of Mexican cloud forest fragments. Biotropica., 37, 337-342.

Baraloto, C., 2001. Tradeoffs between neotropical tree seedling traits and performance in contrasting environments. Ph.D, University of Michigan.

Bégué, L., 1967. Les forêts du nord de la République du Congo (Brazzaville). Chronique phytogéographique. Bois et Forêts des tropiques., 111, 63-76.

Boulvert, Y., 1996. Etude géomorphologique de la république centrafricaine. Carte à 1/1000 000 en deux feuilles Ouest et Est. Notice explicative $n^{\circ} 110$. ORSTOM Editions, Paris. 258 p.

Brown, J.S and Venable D.L., 1986. Evolutionary ecology of seed bank annuals in temporally varying environments. Am. Nat., 127, 31-40.

Chao, A; Li P.C., Agatha, S and Foissner, W., 2006. A statistical approach to estimate soil ciliate diversity and distribution based on data from five continents. Oikos., 114, 479-493.

Chen, H., Cao, M. \& Tang, Y., 2013. Soil seed banks in plantations and tropical seasonal rainforest of Xishuangbanna, South-West China. J. Trop. For. Sci., 25, 375-386.

Chiarucci, A., Enright, N.J., Perry, G.L.W., Miller, B.P and Lamont, B.B., 2003. Performance of nonparametric species richness estimators in a high diversity plant community. Diversity and Distributions., 9, 283-295.

Colwell, R.K., 2013. EstimateS : Statistical estimation of species richness and shared species from samples. Version 9. Persistent URL < purl.oclc.org/estimates >.

Csontos, P and Tamas, J., 2003. Comparisons of soil seed bank classification systems. Seed Science Research., 13, 101-111. 
Daïnou, K., Bauduin, A., Bourland, N., Gillet, J.F., Fétéké, F and Doucet, J.L., 2011. Soil seed bank characteristics in Cameroonian rainforests and implications for postlogging forest recovery. Ecol. Eng., 37, 1499-1506.

Dalling, J.W., Swaine, M.D., Garwood, N.C., 1994. Effect of seedling emergence in tropical soil seed-bank investigations. Functional Ecology., 9, 119-121.

Dos Santos, D.M., Da Silva, K.A., De Albuquerque, U.P., Dos Santos, J.M.F., Reis Lopes, C.G., De Lima Araújo, E., 2013. Can spatial variation and inter-annual variation in precipitation explain the seed density and species richness of the germinable soil seed bank in a tropical dry forest in north-eastern Brazil? Flora., 208, 445-452.

Dove, A.D.M and Cribb, T.H., 2006. Species accumulation curves and their applications in parasite ecology: Review. ScienceDirect., 12, 569-574.

Fayolle, A., Picard, N., Doucet, J-L., Swaine, M., Bayol, N., Bénédet, F., Gourlet-Fleury, S., 2014. A new insight in the structure, composition and functioning of central African moist forests. Forest Ecology and Management., 329, 195-205.

Fayolle, A., Engelbrecht, B., Freycon, V., Mortier, F., Swaine, M., Réjou-Méchain, M., Doucet, J.L., Fauvet, N., Cornu, G., Gourlet-Fleury, S., 2012. Geological substrates shape tree species and trait distributions in African moist forests. PLoS ONE., 7, 1-10.

Freycon, V., 2014. Caractérisation des sols de Loundoungou et de Mokabi (Congo). Rapport de mission DynAfFor, 2 au 24 avril 2014. CIRAD, Montpelier, 64 p.

Garwood, N.C., 1989. Tropical soil seed banks: a review. In: Leck, M.A., Parker, V.T., Simpson, R.L. (Eds.), Ecology of Soil Seed Banks. Academic Press, Inc., New York.

Gond, V., Fayolle, A., Pennec, A., Cornu, G., Mayaux, P., Camberlain, P., Doumenge, C., Fauvet, N and Gourlet-Fleury, S., 2013. Vegetation structure and greenness in Central Africa from Modis multi-temporal data. Philos. T. R. Soc. B 368, 20120309, http://dx.doi.org/10.1098/rstb.2012.0309.

Grandin, U. \& Rydin, H., 1998. Attributes of the seed bank after a century of primary succession on islands in Lake Hjalmaren, Sweden. Journal of Ecology., 86, 293-303.

Hall, J.S and Swaine M.D., 1980. Seed stocks in Ghanaian forest soils. Biotropica., 12, 256-263. Hammond, D.S and Brown, V.K., 1995. Seed size of woody plants in relation to disturbance, dispersal, soil type in wet neotropical forests. Ecology., 76, 2544-2561.

Han, A.R., Sohng, J.E., Barile, J.R., Lee, Y.K., Woo, S.Y., Lee, D.K., Park, P.S., 2012. Comparison of soil seed banks in canopy gap and closed canopy areas between a secondary natural forest and a big leaf mahogany (Swietenia macrophylla King) plantation in the Mt. Makiling Forest Reserve, Philippines. Journal of Environmental Science and Management., 1, 47-59.

Heck, J.K.L., van Belle, G., Simberloff, D., 1975. Explicit calculation of the rarefaction diversity measurement and the determination of sufficient sample size. Ecology., 56, 14591461.

Houle, G and Phillips, D.L., 1988. The soil seed bank of granite outcrop plant communities. Oikos., 52, 87-93.

Hosogi, D., Yonemura, S., Kameyama, A., 2006. Thickness of topsoil setting and effectiveness of fertilizer quantity and malting on banked slope revegetation with forest topsoil. Journal of the Japanese Society of Revegetation Technology., 31, 385-390. 
Hutchinson, J., Keay, R.W.J., Dalziel, J.M., Hepper, F.N., Alston, A.H.G., 1954. Flora of West Tropical Africa: All Territories in West Africa South of Latitude $18^{\circ} \mathrm{N}$ and to the West of Lake Chad, and Fernando Po, vol. 295. Crown Agents for Oversea Governments and Administrations, London, pp. 297-828.

Karakassis, I., 1995. A new method for calculating macrobenthic species richness. Marine Ecology Progress Series., 120, 299-303.

Kellman, M.C., 1970. The viable seed content of some forest soil in coastal British Columbia. Canadian Journal of Botany., 48, 1383-1385.

Kleinschroth, F., Gourlet-Fleury, S., Sist, P., Mortier, F., Healey, J.R., 2015. Legacy of logging roads in the Congo Basin: how persistent are the scars in forest cover? Ecosphere 6, art64.

Kramer, N.B \& Johnson, F.D., 1987. Mature forest seed banks of three habitat types in Central Idaho. Canadian Journal of Botany., 65, 1961-1966.

Legendre, P., Gallagher, E.D., 2001. Ecologically meaningful transformations for ordination of species data. Oecologia., 129, 271-280.

Legendre, P and Legendre, L., 1998. Numerical ecology, 2nd English edn. Elsevier, Amsterdam.

Leicht-Young, S.A., Pavlovic, N.B., Grundel, R., Frohnapple, K.J., 2009. A comparison of seed banks across a sand dune successional gradient at Lake Michigan dunes (Indiana, USA). Plant Ecol., 202, 299-308.

Livingston, R.B \& Allessio, M.L., 1968. Buried viable seed in successional fiel and forest stands, Harvard Forest, Massachusetts. Bull. Torrey Bot. Club., 95, 58-69.

Marcon, E., 2016. Mesures de la Biodiversité. UMR Écologie des forêts de Guyane, http://www.ecofog.gf.

Martins, A.M \& Engel, V.L., 2007. Soil seed banks in tropical forest fragments with different disturbance histories in southeastern Brazil. Ecol. Eng., 31, 165-174.

Moles, A.T., Hodson, D.W and Webb, C.J., 1999. Seed size and shape and persistence in the soil in the New Zealand flora. Oikos., 89, 541-545.

Moore, J.M \& Wein, R.W., 1977. Viable seed populations by soil depth and potential site recolonization after disturbance. Canadian Journal of Botany., 55, 2408-2412.

Morin-Rivat, J., Fayolle, A., Gillet, J.F., Bourland, N., Gourlet-Fleury, S., Oslisly, R., Bremond, L., Bentaleb, I., Beeckman, H., Doucet, J.-L., 2014. New evidence of human activities during the Holocene in the lowland forests of the Northern Congo Basin. Radiocarbon., 56, 209-220.

Nasi, R., Billand, A., Vanvliet, N., 2012. Managing for timber and biodiversity in the Amazon Basin. For Ecol Manage., 268, 103-111.

Oslisly, R., White, L., Bentaleb, I., Favier, C., Fontugne, M., Gillet, J.-F and Sebag, D., 2013. Climatic and cultural changes in the west Congo Basin forests over the past 5000 years. Philosophical Transactions of the Royal Society B: Biological Sciences 368.

Osunkoya, O.O., Ash, J.E., Hopkins, M.S., Graham, A.W., 1992. Factors affecting survival of tree seedlings in North Queensland rainforests. Oecologia., 91, 569-578.

Page, M.J., Baxter, G.S., Lisle, A.T., 2006. Evaluating the adequacy of sampling germinable soil seed banks in semi-arid systems. Journal of Arid Environments., 64, 323-341. 
Pakeman, R.J \& Small, J.L., 2005. The role of the seed bank, seed rain and the timing of disturbance in gap regeneration. Journal of Vegetation Science., 16, 121-130.

Pearson, T.R.H., Burslem, D.F.R.P., Mullins, C.E and Dalling, J.W., 2003. Functional significance of photoblastic germination in neotropical pioneer trees: a seed's eye view. Functional Ecology., 17, 394-402.

Perera, G.A.D., 2005. Spatial heterogeneity of the soil seed bank in the tropical semideciduous forest at Wasgomuwa National Park. Sri Lanka Trop. Ecol., 46, 79-89.

Picard, N et Gourlet-Fleury, S., 2008. Manuel de référence pour l'installation de dispositifs permanents en forêt de production dans le Bassin du Congo. CIRAD, Département Environnements et Sociétés, UPR, Dynamique des forêts naturelles.

Plue, J. \& Hermy, M., 2012. Consistent seed bank spatial structure across semi-natural habitats determines plot sampling. J. Veg. Sci., 23, 505-516.

Poulin, R., 1998. Comparison of three estimators of species richness in parasite component communities. J. Parasitol., 84, 485-490.

Putz, F.E. 1983. Treefall pits and mounds, buried seeds, and the importance of soil disturbance to pioneer trees on Barro Colorado Island, Panama. Ecology., 64, 1069-1074.

Putz, F.E. \& Appanah, B., 1987. Buried seeds, newly dispersed seeds, and the dynamics of a lowland forest in Malaysia. Biotropica., 19, 326-339.

Rampton, H.H \& Ching, T.H., 1970. Persistence of crop seeds in soil. Agronomy Journal., 62, 272-277.

Rao, CR., 1995. A review of canonical coordinates and an alternative to correspondence analysis using Hellinger distance. Qüestiió., 19, 23-63.

Ray, P.M., Steeves, T.A \& Fultz, S.A., 1983. Botany. Saunders College Publishing, Philadelphia.

Roberts, H.A., 1981. Seed banks in soils. Appl. Biol., 6, 1-55.

Rollet, B., 1981. La régénération naturelle dans les trouées, un processus général de la dynamique des forêts tropicales humides : 1ère partie. Bois For. Trop., 201, 3-34.

Shen, Y.X., Liu, W.L., Li, Y.H., Guan, H.L., 2014. Large Sample Area and Size Are Needed for Forest Soil Seed Bank Studies to Ensure Low Discrepancy with Standing Vegetation. PLoS ONE., 9, 10-35.

Symonides, E., 1986. Seed bank in old-field successional ecosystems. Ecologia Polska., 34, 329.

Thompson, K and Grime, J.P., 1979. Seasonal variation in the seed bank of herbaceous species in ten contrasting habitats. J. Ecol., 67, 893-921.

van der Valk, A.G and Davis, C.B., 1978. The role of seed banks in the vegetation dynamics of prairie glacial marshes. Ecology., 59, 322-335.

Vazquez-Yanes, C., Orozco-Segovia, A., 1993. Patterns of seed longevity and germination in the tropical rainforest. Annu. Rev. Ecol. System., 24, 69-87.

Venable, D.L., 1989. Modelling the evolutionary ecology of seed banks. Pages 67-90 in M. A. Leck, V. T. Parker, R.L. Simpson, editors. Ecology of soil seed banks. Academic Press, New York, New York, USA.

Verelst, L., 2009. Harmonized World Soil Database Viewer. FAO, CAS, IIASA, ISRIC, JRC. 
Walther, P., Resch, K.J., Rudolph, T., Schenck, E., Weinfurter, H., Vedral, V., Aspelmeyer, M \& Zeilinger, A., 2005. Experimental One-Way Quantum Computing. Nature., 434, 169176.

Walther, B.A and Morand, S., 1998. Comparative performance of species richness estimation methods. Parasitology., 116, 395-405.

Walther, B.A and Martin, J.L., 2001. Species richness estimation of bird communities: how to control for sampling effort ? Ibis., 143, 413-419.

Warr, S., Thompson, K., Kent, M., 1993. Seed banks as a neglected area of biogeographic research: a review of literature and sampling techniques. Prog. Phys. Geog., 17, 329347.

Wilson, B.G et Witkowski, E.T.F., 2003. Seed banks, bark thickness, and changes in age and size structure (1978-1999) of the African savanna tree, Burkea africana. Plant Ecology., 167, 151-162.

Witkowski, E.T.F and Garner, R.D., 2008. Seed production, seed bank dynamics, resprouting and long-term response to clearing of the alien invasive Solanum mauritianum in a temperate to subtropical riparian ecosystem. South African. Journal of Botany., 74, 476-484.

Young, K.R., Ewel, J.J., Brown, J.B., 1987. Seed dynamics during forest succession in Costa Rica. Vegetatio., 71, 157-173.

Zhan, J and Maun, M.A., 1994. Potential for Seed Bank Formation in Seven Great Lakes Sand Dune Species. American Journal of Botany., 81, 387-394.

Annexe 1. Positioning of the variables (species) on axes 1 and 2, and total proportion of the explained characteristic values by each axis of the RDA for the FL and FM sites. (A): FM site; (B): FL site.

(A)
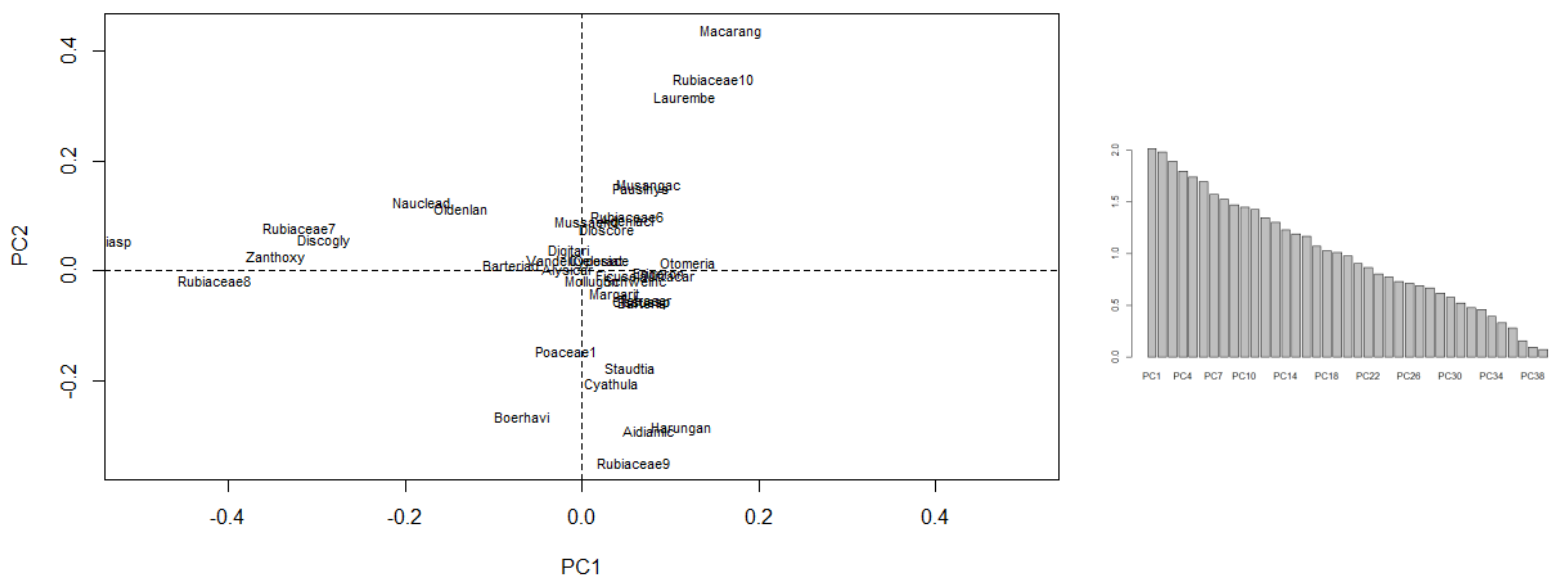
International Journal of Agriculture, Environment and Bioresearch

Vol. 5, No. 06; 2020

ISSN: $2456-8643$

(B)
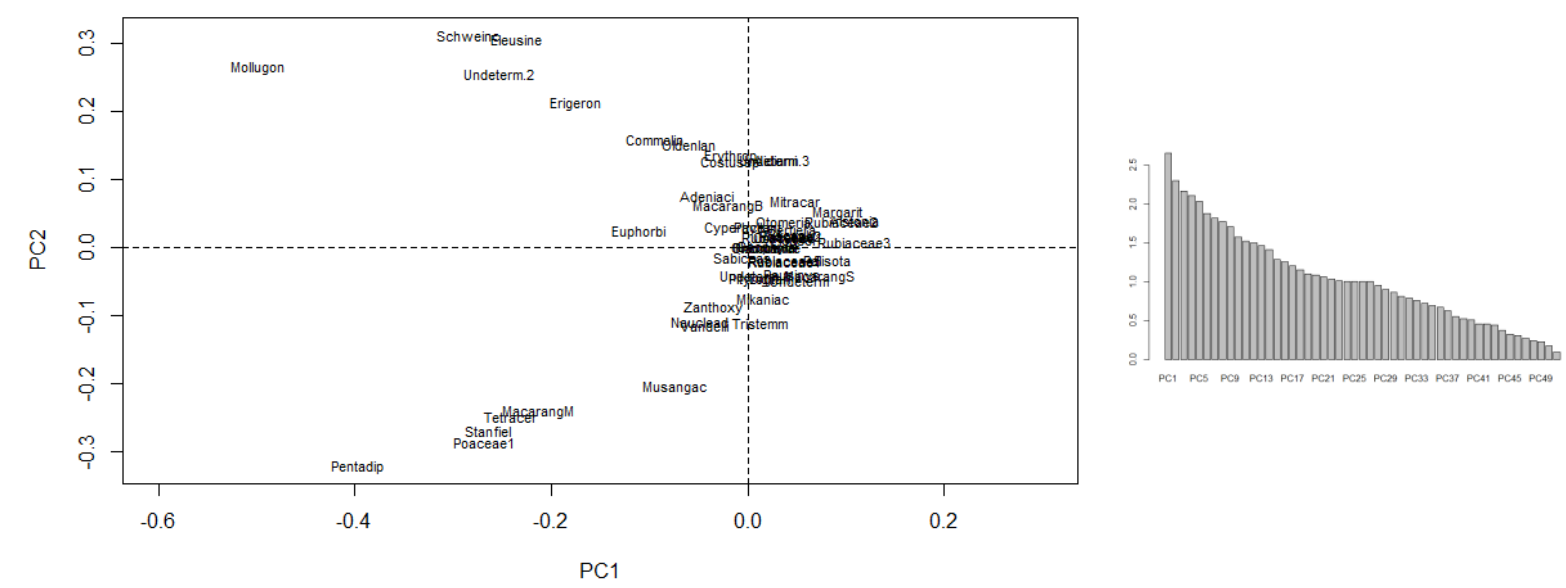